\title{
O regime jurídico do juízo de admissibilidade dos recursos criminais dirigidos aos Tribunais Superiores conforme o $\mathrm{CPC} / 2015$
}

\author{
The legal regulation applicable to the admissibility of criminal \\ appeals to Superior Courts according to the CPC/2015
}

Francisco de Assis do Rêgo Monteiro Rocha Jr. ${ }^{1}$

Universidade Federal do Paraná - Curitiba, Paraná, Brasil

francisco@monteirorocha.com

http://lattes.cnpq.br/9457945336008870

https://orcid.org/0000-0003-3545-2894

\begin{abstract}
Resumo: A gradual implantação de um modelo de precedentes no sistema jurídico brasileiro não foi formalmente inserida no Código de Processo Penal (CPP). Nada obstante, é de se debater se os efeitos desse novo paradigma também estão (ou estarão) sendo sentidos na seara processual penal. Para além de todos os temas que poderiam ser discutidos a partir dessa perspectiva, no presente artigo enfrentaremos especificamente as modificações do regime jurídico do juízo de admissibilidade dos recursos especiais e extraordinários criminais, com o advento do Código de Processo Civil (CPC 2015). Trata-se de discussão a qual deve o processo penal se voltar, tendo-se em conta suas importantíssimas aplicações e desdobramentos práticos para as partes que galgam as cortes superiores, bem como para os respectivos órgãos julgadores. A hipótese da qual partimos é a de que houve efetivas mudanças na forma como os recursos criminais dirigidos aos tribunais superiores devem ser elaborados e julgados em virtude do $\mathrm{CPC} / 15$. Para tanto, apresentaremos os resultados da análise realizada da legislação aplicável, da jurisprudência que tem sido produzida sobre o tema, bem como apresentaremos as contribuições de autores que já se debruçaram sobre tal temática.
\end{abstract}

1 Professor Adjunto do Departamento de Direito Penal e Processo Penal da Universidade Federal do Paraná (UFPR). Doutor em Direito pela UFPR. Advogado. 
Palavras-chave: recurso especial criminal; recurso extraordinário criminal; Código de Processo Civil de 2015; juízo de admissibilidade.

ABSTRACT: The gradual implementation of a precedent model in the Brazilian legal system was not formally inserted in the Code of Criminal Procedure (CPP). Nevertheless, it is important to debate whether the effects of this new paradigm are also (or will be) being felt in the criminal procedure. Beyond all the topics that could be discussed from this perspective, in this article we will specifically face the modifications of the of the criminal appeals to the superior courts admissibility, due to the advent of the Civil procedure Code (CPC 2015). This is a discussion which should the criminal process take place, considering its very important applications and practical developments for the parties in Superior Courts criminal proceedings, as well as for their Judging bodies. The hypothesis of which we depart is that there have been effective changes in the way criminal appeals to the superior courts should be elaborated and judged due to the CPC 2015. To reach that, we will present the results of the analysis carried out of the applicable legislation, the jurisprudence that has been produced on the subject, and we will present the contributions of authors who have already studied this theme.

KeYwords: criminal appeals to Superior Courts; 2015 Civil procedure code (CPC 2015); admissibility.

SUMÁRIO: 1. Introdução. 2. O Processo Penal rumo a um sistema de precedentes? 3. A nova sistemática do exame de admissibilidade dos recursos dirigidos aos tribunais superiores. 4 . Recursos que serão negados, sem análise do tema federal ou constitucional veiculado. 4.1. Tema do recurso não teve repercussão geral reconhecida ou acórdão recorrido acolhe entendimento da repercussão geral. 4.2. Acórdão em conformidade com entendimento do STF ou do STJ. 5. Recursos que serão encaminhados para retratação do órgão no qual foi julgado o acórdão recorrido 6. Recursos que serão sobrestados - e as questões correlatas da manutenção da prisão cautelar e da prescrição. 6.1. É razoável a execução antecipada da pena de processo suspenso por aguardar decisão final de Repercussão Geral ou Recurso Repetitivo? 6.2. Como incidiria os prazos prescricionais em processo suspenso por aguardar decisão final de Repercussão Geral ou Recurso Repetitivo? 7. Recursos cuja admissibilidade será analisada e seleção dos representativos da controvérsia. 7.1. Juízo de admissibilidade dos recursos. 7.2. Seleção de recurso representativo de controvérsia. 8 . Conclusões. 


\section{INTRODUÇÃO}

Há inúmeros debates sobre os fundamentos - ou a lógica de existência - dos recursos em processos judiciais. Há argumentos em sua defesa (como a noção da falibilidade humana; como o fato dos tribunais serem compostos por juízes mais experientes; como a pressão sobre os magistrados de que a possibilidade de revisão dos julgados provoca no sentido de mais diligência, etc.) e há argumentos contrários ao instituto (como a inocuidade da primeira instância se o recurso for provido ou da segunda instância se não o for; como o desprestígio à justiça provocado pelas decisões contraditórias, etc.) ${ }^{2}$.

Para além desses argumentos, há que se reparar que a existência dos recursos e a necessidade do aprofundamento e refinamento de sua(s) sistemática(s), é corolário da existência de mecanismos de controle sobre os atos realizados pelos três poderes, sejam eles quais forem. Assim como há a possibilidade de os atos administrativos e legislativos serem controlados pela via judicial, vê-se que também as decisões judiciais devam se submeter a controles, por meio do que se verificaria sua acurácia fática, legalidade e constitucionalidade ${ }^{3}$. Trata-se de decorrência da própria constitucionalização da nossa estrutura jurídico-política desde 1988.

De todo o modo, e independentemente do fundamento que lhe ancora, o fato é que se enraizaram em nosso sistema jurídico diferentes meios de impugnação das decisões judiciais ${ }^{4}$. Na seara criminal, por um lado, podemos destacar os recursos que comportam ampla devolutividade e consequente revolvimento de todas as questões fáticas e jurídicas, como é o caso da apelação criminal. De outro, podemos voltar nossa mirada para os recursos que só contemplam a revisão dos pressupostos jurídicos da decisão atacada, como é o caso dos recursos dirigidos aos

2 Para um painel sobre o assunto, LOPES JR., Aury. Direito processual penal. 9. ed. rev. E atual. São Paulo: Saraiva, 2012. p. 1151-1155; BADARÓ, Gustavo Henrique. Processo Penal. 6. ed. rev., atual. e ampl. São Paulo: Thomson Reuters Brasil, 2018; p. 833-870; RANGEL, Paulo. Direito processual penal. 22. ed. São Paulo: Atlas, 2014, p. 951-1007.

3 Cf. ROCHA JÚNIOR, Francisco de Assis do Rego Monteiro. Recurso Especial e Extraordinário Criminais. São Paulo: Saraiva, 2013.

4 MEDINA, José Miguel Garcia. O prequestionamento nos recursos extraordinário e especial. São Paulo: Revista dos Tribunais, 2005, 4a . ed., p. 27-29. 
tribunais superiores - cujo exame de admissibilidade será verticalizado no presente artigo.

Antes disso, porém, cabe a indagação: o que significa dizer que algumas decisões só admitem reexame em seus pressupostos jurídicos? Ou, em outro olhar sobre a mesma questão, o que são recursos que só debatem as questões jurídicas da decisão impugnada?

A explicação dessa sistemática parte da constatação de que os fatos e as provas somente são discutidos na primeira instância, pelo juiz de direito com competência criminal, e pelas Câmaras e Turmas Criminais do Tribunal respectivo. Dessa feita, a instância revisora nas Superiores Instâncias não poderá reanalisar as provas para reformar o julgamento e deliberar que os fatos não se deram como decidido na instância a quo. Igualmente será vedado reformar a decisão para decidir que fato assentado no decisum inferior não existiu. Discute-se, nessa seara, somente se lei e Constituição aplicadas no deslinde da causa foram interpretadas de forma coerente e harmônica com o sistema jurídico.

Seguindo nosso raciocínio, conclui-se que as impugnações dirigidas aos Tribunais superiores estão restritas à análise da escorreita aplicação do Direito como é o caso do recurso especial, previsto no art. 105, III, e o recurso extraordinário, positivado no art. 102, III, ambos da Constituição da República.

Como dito acima, o que pretendemos abordar no presente artigo é exatamente o juízo de admissibilidade dessas espécies recursais, que foram bastante impactadas com o advento do CPC/2015. Para tanto, e partindo do pressuposto de que referidas mudanças estão sendo efetivamente aplicadas no processo penal, faremos análise da novel legislação à luz de como a jurisprudência tem se debruçado sobre o tema ${ }^{5}$, ou sobre como sobre ele deveria se debruçar.

Esclareça-se, por oportuno, que por se tratar de tema que ainda não despertou a atenção da dogmática processual penal brasileira, no

5 É de se observar que, ao longo do presente trabalho, nem sempre pudemos fazer referência à jurisprudência, visto que optamos por realizar recorte adstrito exclusivamente aos Cortes Superiores. Isso se deve ao fato de que, como se trata de nova legislação, eventuais idiossincrasias dos Tribunais Estaduais na interpretação dessa norma poderiam turvar a visualização mais límpida e decantada que se pretende realizar sobre a discussão proposta. 
presente artigo, a crítica científica perde protagonismo para a descrição compreensiva. É de se ressaltar que, ao lado da crítica, tão necessária e importante, é também fundamental compreender a sistemática de instrumentos dogmáticos. Esse é o comedido objetivo desse artigo.

Desde tal mirada, ao final desse estudo, poderemos apontar as modificações que necessariamente deverão ser enfrentadas pelos operadores jurídicos que se dedicam em termos teóricos ou práticos às questões relacionadas aos recursos criminais dirigidos aos tribunais superiores.

\section{O Processo Penal rumo a um sistema de precedentes?}

Temos visto a paulatina implantação de um modelo de precedentes em nosso sistema jurídico ${ }^{6}$. De fato, como apontam Nunes e Horta, "nas últimas duas décadas, foram implementadas inúmeras reformas processuais de valorização do direito jurisprudencial, desde a criação dos enunciados de súmulas (inicialmente, apenas nos regimentos internos dos tribunais e, posteriormente, na legislação, por meio da lei n. 8.756/98, que deu nova redação ao art. 557 do CPC/73, e da lei no 11.2.76/06, que acrescentou o $\$ 1^{\circ}$ ao art. 518 do mesmo diploma)" ". Ainda fazem alusão os autores à “(...) Súmula Vinculante (art. 103-A do CPC, criado pela

6 Sobre o tema, HORTA, André Frederico e NUNES, Dierle. Aplicação de precedentes e distinguishing no CPC/2015: uma breve introdução. In: Precedentes (Coleção Grandes Temas do Novo CPC, v. 3). DIDIER JR., Fredie... et al. Salvador: Juspodium, 2016; OLIVEIRA, Ana Carolina. Diferenças e semelhanças entre os sistemas da civil law e da common law. Direito Público (Porto Alegre), vol. 12, n. 64, 2015, p. 109-126; ZANETI JR., Hermes. Precedentes normativos formalmente vinculantes. In: Precedentes (Coleção Grandes Temas do Novo CPC, v. 3). DIDIER JR., Fredie... et al. Salvador: Juspodium, 2016; STRECK, Lênio Luiz e Streck e ABBOUD, Georges. O que é isto - o precedente judicial e as súmulas vinculantes? Porto Alegre: Livraria do Advogado, 2014; STRECK, Lenio Luiz. Precedentes Judiciais e Hermeneutica: o sentido da vinculação no CPC/2015. Salvador: Juspodium, $2^{a}$ edição, 2019.LOPES FILHO, Juraci Mourão. Os precedentes judiciais no constitucionalismo contemporâneo. 2 ed. rev. e atual. Salvador: Juspodium, 2016; TARUFFO, Michele. Precedente e jurisprudência. Revista de Processo: RePro, v. 36, n. 199, set. 2011.

7 HORTA, André Frederico e NUNES, Dierle. Aplicação de precedentes e distinguishing no CPC/2015: uma breve introdução. In: Precedentes (Coleção Grandes Temas do Novo CPC, v. 3). DIDIER JR., Fredie... et al. Salvador: Juspodium, 2016, pg. 04. 
Emenda Constitucional no 45/04), passando pelo julgamento liminar de demandas repetitivas (art. 285-A do CPC/73, introduzido pela lei no 11.277/06), e, por fim, introdução das técnicas de julgamento de recursos excepcionais repetitivos por amostragem (art. 102, § $3^{\circ}$, da CR, introduzido pela EC no 45/04, e arts. 543-A a 543-C do CPC/73, criados pelas Leis no 11.418/06 e 11.672/08)" ${ }^{8}$.

Como se vê da visualização panorâmica das recentes reformas legislativas que vivenciamos nos últimos anos, não houve qualquer alteração explícita do Código de Processo Penal (CPP) mirando a implantação de um sistema de precedentes, nada obstante a guinada do nosso modelo de civil law para feições típicas do common law. Porém, não seria equivocado se apontar para o fato de que esse fenômeno tem também se refletido na seara processual penal.

Isso ocorre porque apesar do CPP não ter sido modificado no sentido de formalmente prever um sistema de obediência aos julgados anteriores sobre o tema, a nova redação do art. 638 desse Código procedimental ${ }^{9}$ expressamente estabelece que os recursos criminais dirigidos aos tribunais superiores serão processados e julgados por "leis especiais, pela lei processual civil e pelos respectivos regimentos internos” ${ }^{10}$. Trata-se

8 HORTA, André Frederico e NUNES, Dierle. Aplicação de precedentes e distinguishing no CPC/2015: uma breve introdução. In: Precedentes (Coleção Grandes Temas do Novo CPC, v. 3). DIDIER JR., Fredie... et al. Salvador: Juspodium, 2016, pg. 04. Patrícia Perrone caminha no mesmo sentido: "A indiscutível expansão do controle concentrado de constitucionalidade, as discussões empreendidas pelo Supremo Tribunal Federal acerca da eficácia transcendente da motivação nesta sede, e, finalmente, a criação da súmula vinculante, através da Emenda Constitucional n ${ }^{\circ} 412004$, apontam para um novo momento da hermenêutica constitucional. Tais fatos expressam a evolução dos mecanismos de jurisdição constitucional, no Brasil, para uma direção comum, da atribuição de uma força vinculante geral aos precedentes judiciais”. (MELLO, Patrícia Perrone Campos. Precedentes: o desenvolvimento judicial do direito no constitucionalismo contemporâneo. São Paulo: Renovar, 2008, pg. 01).

9 Redação dada pelas alterações introduzidas no Código de Processo Penal pela Lei 13.964/2019, que ficou conhecida pela insólita alcunha de "pacote anticrime".

10 "Art. 638. O recurso extraordinário e o recurso especial serão processados e julgados no Supremo Tribunal Federal e no Superior Tribunal de Justiça na forma estabelecida por leis especiais, pela lei processual civil e pelos respectivos regimentos internos." 
da positivação, através da Lei 13.964/2019, de uma lógica que imperava materialmente: sem embargo das demais matérias, que aqui não serão abordadas por conta dos estreitos limites do presente artigo, no que diz respeito à sistemática dos recursos, as alterações processuais civis são analogicamente trazidas e faticamente implementadas no processo penal.

Porém, não se trata de uma transposição automática. Há alterações que são implementadas no processo penal, e outras tantas que passam ao largo dele. Diante dessa constatação, poderíamos indagar: quais são os critérios para se aplicar a lei processual civil ao processo penal e para não se aplicar? Ainda que seja tema que clama por uma verticalização científica mais pormenorizada, muito provavelmente estaria correto apontarmos para o fato de que as normas externas são aplicadas ao processo penal, quando facilitam a administração da justiça, a celeridade processual, e de alguma forma, a labuta jurisdicional, como é o caso da exigência da demonstração de repercussão geral nos processos penais, como se verifica do entendimento do STF sobre o tema ${ }^{11}$. De outro lado, quando se trata de prazos mais elásticos trazidos pela legislação processual civil, ou maior amplitude de direitos fundamentais do acusado, verifica-se, para se dizer o menos, uma reticência da jurisprudência na transposição para o processo penal dessas garantias, como se verifica, por exemplo, da não incidência dos maiores prazos que são previstos no processo civil. É o que se depreende, por todos, do Agravo em Recurso Extraordinário 1183595 relatado pelo Min. Roberto Barroso, em julgamento realizado pela Primeira Turma do STF em 29/11/2019

11 Dentre tantos, verifica-se essa questão do entendimento exarado no Agravo Regimental nos Embargos de Declaração no Recurso Extraordinário com agravo 1.200.951, relatado pelo Min. Gilmar Mendes, em julgamento realizado pela Segunda Turma do STF em 18/10/2019.

12 Trecho da ementa contextualiza a questão: “(...) 1. O acórdão recorrido foi publicado em 26.06.2018 e a petição do recurso foi protocolada no Tribunal de origem somente em 13.08.2019, ou seja, após o término do prazo recursal de 15 (quinze) dias, nos termos do art. 994, VII, c/c os arts. 1.003, § 5 , e 1.029 do Código de Processo Civil, bem como do art. 798 do Código de Processo Penal. 2. A aplicação do novo CPC a instituto de direito processual penal deve ser autorizada apenas em situações excepcionalíssimas, notadamente na existência de lacuna normativa. No caso, mostra-se inaplicável o art. 219 do CPC/2015, tendo em vista que, tratando-se de prazo processual penal, o modo de sua contagem é disciplinado pelo art. 798 do Código de Processo Penal. Precedentes. 3. Agravo interno a que se nega provimento". 
As discussões oriundas da adaptação do processo penal ao sistema de precedentes, que acabou por se concretizar na esfera processual penal através da repercussão geral e dos recursos repetitivos, seriam inúmeras. Assim, e apesar da amplitude que esse debate enseja, nos estreitos limites desse artigo enfrentaremos somente um dos possíveis aspectos que dali se originam, como já apontado na introdução. Nosso enfoque pode ser resumido nas seguintes indagações: foi modificado o regime jurídico do juízo de admissibilidade dos recursos especiais e extraordinários criminais com o advento do Código de Processo Civil (CPC 2015)? ${ }^{13}$ Se houve modificação, quais teriam sido elas? Diante desse novo quadro, como isso pode impactar a interposição e o julgamento dos recursos especial e extraordinário criminais?

O que se pode adiantar desde logo: efetivamente temos um novo cenário jurídico que deve, obrigatoriamente, ser conhecido por aqueles que manejam essas espécies recursais na esfera criminal. Nosso intento aqui, sem qualquer pretensão de esgotar o assunto, é o de trazermos algumas das principais linhas dessas mudanças e como elas impactarão as interposições, acompanhamento e julgamentos dos recursos extraordinários pelas partes.

Para tanto, antes de adentrarmos no tema propriamente dito, vamos dar alguns passos atrás, e trazer à tona alguns dos elementos imprescindíveis para termos uma melhor compreensão desse cenário, como se faz no item abaixo.

\section{A NOVA SISTEMÁTICA dO EXAME DE ADMISSIBILIDADE DOS RECURSOS DIRIGIDOS AOS TRIBUNAIS SUPERIORES}

Como se sabe ${ }^{14}$, após a publicação do acórdão que julga os embargos de declaração interpostos em face do acórdão oriundo do julgamento

13 No âmbito do processo penal, e referentemente às mudanças trazidas pelo CPC/2015, veja-se VASCONCELLOS, Vinicius G. Direito ao recurso no processo penal. São Paulo: RT, 2019; KIRCHER, Luis Felipe. Uma Teoria dos Precedentes Vinculantes no Processo Penal. Salvador: JusPodivm, 2018.

14 Para um quadro mais amplo de toda a discussão referente aos recursos especial e extraordinários criminais, remete-se o leitor para ROCHA JÚNIOR, Francisco de Assis do Rego Monteiro. Recurso Especial e Extraordinário 
da apelação criminal (ou do próprio acórdão que julga a apelação) ${ }^{15}$, a parte que sucumbiu terá o prazo de 15 (quinze) dias para interpor os recursos especial e extraordinário criminais. ${ }^{16}$ Após as intimações para a apresentação das contrarrazões, que devem ser apresentadas no mesmo prazo, e seu respectivo protocolo, os autos serão conclusos ao Presidente ou Vice-Presidente (conforme disponha o regimento interno do Tribunal local) para que seja realizado o juízo de admissibilidade do(s) recurso(s) raro(s).

Anteriormente ao Código de Processo Civil (CPC/2015), caberia ao Presidente ou Vice-Presidente do Tribunal local analisar a viabilidade jurídica do recursos interposto, sem adentrar no respectivo mérito, para ao final concluir se o recurso deveria ser admitido (quando cumpria os requisitos legais ordinários e havia tema constitucional ou infraconstitucional a ser debatido nas instâncias superiores) ou se ao contrário, não deveria ser admitido (quando se dava a hipótese contrária: ou não cumpria os requisitos legais e/ou não havia tema de índole

Criminais. São Paulo: Saraiva, 2013. Também analisando o tema, indica-se a obra de BADARÓ, Gustavo. Manual dos recursos penais. São Paulo: RT, 2018.

15 Recomenda-se que o acórdão que julga a apelação criminal seja inicialmente desafiado através de embargos de declaração, para, posteriormente, ser interposto o recurso especial e o extraordinário. As razões jurídicas para tanto podem ser resumidas no fato de que todos os temas devem ser debatidos previamente no Tribunal local, para que possam ser revistos nas Cortes Superiores, sob pena de não terem sido prequestionados. Mais sobre o tema: MEDINA, José Miguel Garcia. Prequestionamento e repercussão geral e outras questões relativas aos recursos especial e extraordinário. $5^{\mathrm{a}}$ ed. rev. e amp. São Paulo: RT, 2009; MANGONE, Katia Aparecida. Prequestionamento e questões de ordem pública no recurso extraordinário. São Paulo: Saraiva, 2013; PORTELLA, Glória Maria Guimarães de Pádua Ribeiro. Teoria crítica do recurso especial (jurisprudência e doutrina). Rio de Janeiro: Lumen Juris, 2004; ROCHA JÚNIOR, Francisco de Assis do Rego Monteiro. Recurso Especial e Extraordinário Criminais. São Paulo: Saraiva, 2013; BADARÓ, Gustavo. Manual dos recursos penais. São Paulo: RT, 2018.

16 É de se fazer referência ao fato de que nos processos penais, o prazo de 15 (quinze) dias é contado em dias corridos, conforme entendimento do STF. Por todo, veja-se: "Agravo regimental no Recurso Extraordinário com Agravo. Penal e Processo Penal. 2. Contagem do prazo em matéria penal. Dias úteis. Inaplicabilidade. 3. Em matéria penal, conta-se o prazo em dias corridos. 4. Negativa de provimento ao agravo regimental. (ARE 1115857 AgR, Relator(a): Min. Gilmar Mendes, Segunda Turma, julgado em 08/02/2019). 
constitucional ou infraconstitucional a ser enfrentado nos Tribunais Superiores). Esse era, em síntese, o conteúdo dessa fase processual a qual se denomina juízo de admissibilidade dos recursos dirigidos aos tribunais superiores.

Ocorre que, com o advento do CPC/2015 passamos a ter um novo regramento para esse momento processual, qual seja, aquele estatuído pelo art. 1.030 do CPC 2015. Tal norma estabelece que o órgão competente para analisar a admissibilidade ou a inadmissibilidade do recurso especial ou extraordinário interposto deverá percorrer um dos cinco caminhos indicados na norma indicada: i) negar seguimento ao recurso; ii) encaminhar os autos para a câmara ou turma que realizou o julgamento para que se retrate, conformando a decisão aos precedentes cabíveis na espécie; iii) sobrestar o recurso que verse sobre controvérsia de caráter repetitivo, que ainda não tenha sido decidida pelos Tribunais Superiores; iv) selecionar o recurso como representativo da controvérsia constitucional ou infraconstitucional; e v) realizar o juízo de admissibilidade, dando ou negando seguimento ao recurso.

Como se vê, e na esteira de Côrtes, "o legislador preocupou-se, em síntese, em especificar como poderes do presidente ou do vice-presidente do tribunal prolator da decisão recorrida, providências que devem ser tomadas nos casos de recursos repetitivos e de repercussão geral. Incorporou, ainda, à legislação, a sistemática adotada jurisprudencialmente pelo STF que à luz do CPC de 1973 autorizava o indeferimento de recursos extraordinários quanto já houvesse precedente acerca da falta de repercussão geral" ${ }^{17}$.

Comparativamente ao regramento anterior - em que o juízo de admissibilidade se limitava a dar ou não seguimento ao recurso interposto - trata-se de profunda modificação, que adapta a sistemática ao paradigma dos precedentes. Analisa-se, nos tópicos abaixo, cada uma dessas hipóteses positivadas no CPC/2015, como elas já tem se refletido no cotidiano forense criminal e como deveriam se refletir.

17 CÔRTES, Osmar Mendes Paixão. Recursos para os tribunais superiores: recurso extraordinário, recurso especial, embargos de divergência e agravos. $4^{\mathrm{a}} \mathrm{ed}$. Brasília: Gazeta Jurídica, 2017, p. 136. 


\section{Recursos que SERÃo negados, SEM ANÁlise do tema federal OU CONSTITUCIONAL VEICULADO}

Na primeira hipótese que pode ser aqui debatida, verifica-se do inciso I do art. 1030 do CPC $/ 2015^{18}$ que a presidência ou vice-presidência do tribunal local, ao realizar o juízo de admissibilidade do recurso especial e/ou extraordinário interposto, poderá, desde logo, negar-lhe seguimento, sem análise do tema federal ou constitucional veiculado ${ }^{19}$.

Isso poderá ocorrer em duas circunstâncias. Na primeira delas, nos termos da alínea "a" do inciso I analisado, tem-se a situação retratada no "recurso extraordinário que discuta questão constitucional à qual o Supremo Tribunal Federal não tenha reconhecido a existência de repercussão geral ou a recurso extraordinário interposto contra acórdão que esteja em conformidade com entendimento do Supremo Tribunal Federal exarado no regime de repercussão geral”. A segunda, diz respeito a "recurso extraordinário ou a recurso especial interposto contra acórdão que esteja em conformidade com entendimento do Supremo Tribunal Federal ou do Superior Tribunal de Justiça, respectivamente, exarado no regime de julgamento de recursos repetitivos". Aprofundemo-nos em cada dessas duas hipóteses separadamente.

\subsection{TEMA DO RECURSO NÃO TEVE REPERCUSSÃo GERAL RECONHECIDA OU ACÓRDÃO RECORRIDO ACOLHE ENTENDIMENTO DA REPERCUSSÃO GERAL}

Imprimindo efetividade ao paradigma dos precedentes positivado pelo CPC/2015, retrata a primeira hipótese o efeito vinculante dos

18 Art. 1.030. (...) I - negar seguimento: a) a recurso extraordinário que discuta questão constitucional à qual o Supremo Tribunal Federal não tenha reconhecido a existência de repercussão geral ou a recurso extraordinário interposto contra acórdão que esteja em conformidade com entendimento do Supremo Tribunal Federal exarado no regime de repercussão geral; b) a recurso extraordinário ou a recurso especial interposto contra acórdão que esteja em conformidade com entendimento do Supremo Tribunal Federal ou do Superior Tribunal de Justiça, respectivamente, exarado no regime de julgamento de recursos repetitivos.

19 Abordando o tema, veja-se: CAMBI, Eduardo, DOTTI, Rogéria, PINHEIRO, Paulo Eduardo d'Arce, MARTINS, Sandro Gilberto, e KOZIKOSKI, Sandro Marcelo. Curso de Processo Civil completo. São Paulo: RT, 2017, pg. 1612. 
julgamentos de repercussão geral. Quando o Supremo Tribunal Federal não reconhece repercussão geral ao tema do recurso interposto pela parte, o recurso não será conhecido. Sim, pois se já houve a deliberação pelo STF de que o tema não merece a sua atenção, ou seja, não teve a repercussão geral reconhecida, somente cabe dar efetividade à deliberação, e não revisitá-la a cada recurso interposto, sob pena de se negar eficácia ao próprio instituto.

Por exemplo, nos termos do Tema 182 de Repercussão Geral, debatido no âmbito do Agravo de Instrumento 742460, cujo julgamento ocorreu em 27 de agosto de 2009, entendeu-se que eventual equívoco na valoração das circunstâncias judiciais previstas no art. 59 do Código Penal, referente à fundamentação da fixação da pena-base, não ofende os princípios constitucionais da individualização da pena e da fundamentação das decisões judiciais, tendo natureza infraconstitucional. Para o STF, o debate acerca da má aplicação do art. 59 do Código Penal não diz respeito à discussão dos princípios constitucionais acima elencados, mas sim de discussão ligada à interpretação de índole legal, e impugnável pela via especial. Por tais razões, não foi reconhecida a repercussão geral do tema, e eventuais recursos extraordinários que venham a ser interpostos com base na mesma discussão sequer serão conhecidos, por força desse entendimento.

Tampouco será conhecido o recurso na hipótese de ter sido reconhecida a repercussão geral da tese e o acórdão recorrido ter se firmado no mesmo sentido. Aqui se aplica o inverso da hipótese analisada acima: se foi reconhecida a repercussão geral ao tema, e se o Tribunal de origem julgou a demanda levando em conta referido entendimento, recurso contra esse entendimento não será admitido, nos termos do artigo em comento.

Como exemplo dessa situação pode-se colher o Recurso Extraordinário 579.167, julgado em 16 de março de 2013, e que redundou no Tema de Repercussão Geral n. 59, assim ementado: "A Lei no 11.464/07, que majorou o tempo necessário a progredir-se no cumprimento da pena, não se aplica a situações jurídicas que retratem crime cometido em momento anterior à respectiva vigência”. De tal forma, sendo prolatado acórdão por tribunais locais que reafirmem tal entendimento, ou seja, de que a lei mais grave só poderá reger casos que ocorram posteriormente à sua vigência, descaberá qualquer irresignação do Ministério Público ou da Assistência de Acusação quanto ao tema. 
É fácil se depreender da discussão que já se anuncia que, para além do conhecimento das leis penais e processuais penais, codificadas e extravagantes, atualmente, faz-se imperioso também se conhecer os precedentes em sede de repercussão geral e recurso repetitivo. Sem o hábil manejo dessas decisões, haverá uma enorme dificuldade às partes, quando não uma impossibilidade, de se escalar o STF e o STJ através de Recurso Extraordinário e Recurso Especial, respectivamente. E essa constatação, como se verá abaixo, não é importante somente para essa faceta do tema ora apresentado, sendo relevante também para as hipóteses de recurso excepcional interposto em face de acórdão em conformidade com entendimento do STF ou do STJ. É o que se debate no subitem abaixo.

\subsection{AcóRdÃo EM CONFORMIDADE COM ENTENDIMENTO dO STF OU DO STJ}

O segundo caso de indeferimento prefacial do recurso extraordinário reside na circunstância dele ser interposto contra acórdão que esteja em conformidade com entendimento do Supremo Tribunal Federal ou do Superior Tribunal de Justiça exarado no regime de julgamento de recursos repetitivos, nos termos da alínea "b", do inciso I, do artigo ora em comento ${ }^{20}$.

A parte da redação da alínea em comento que se refere ao Supremo Tribunal Federal parece deslocada. O tema já foi positivado na alínea anterior, e sob o enfoque do aspecto aqui abordado, não haveria razão para novamente ser debatido. Ademais, não há o instituto dos recursos repetitivos no âmbito do Supremo Tribunal Federal, lá vigendo, como se sabe, a repercussão geral para imprimir efeito erga omnes às respetivas decisões.

Assim, o que nos interessa aqui é a segunda parte da alínea, que se refere à acórdão que esteja em conformidade ao entendimento do Superior Tribunal de Justiça exarado no regime de julgamento de recursos repetitivos. Aqui se impõe o mesmo raciocínio acima desenvolvido e que pode ser demonstrado no seguinte exemplo. O tema de recurso

20 Abordando o tema, veja-se: CAMBI, Eduardo, DOTTI, Rogéria, PINHEIRO, Paulo Eduardo d'Arce, MARTINS, Sandro Gilberto; KOZIKOSKI, Sandro Marcelo. Curso de Processo Civil completo. São Paulo: RT, 2017, pg. 1612. 
repetitivo 157, oriundo da afetação à Terceira Seção do Superior Tribunal de Justiça dos Recursos Especiais 1688878/SP e 1709029/MG, assentou que "Incide o princípio da insignificância aos crimes tributários federais e de descaminho quando o débito tributário verificado não ultrapassar o limite de $R \$ 20.000,00$ (vinte mil reais), a teor do disposto no art. 20 da Lei n. 10.522/2002, com as atualizações efetivadas pelas Portarias 75 e 130, ambas do Ministério da Fazenda". De tal forma, sendo o crime tributário praticado em patamar inferior a esse valor, e sendo absolvido o recorrente por essa razão, ou tendo havido trancamento do processo crime ao qual respondia em virtude dessa discussão, o acórdão de segundo grau que assentar esse entendimento não poderá ser atacado pela via especial, sob pena da irresignação sequer ser conhecida.

Novamente, como adrede anunciado, fica ressaltada a importância do fiel manejo dos precedentes em sede de recursos repetitivos e repercussão geral também, nos processos penais, que, como exposto no item 2 acima, passam a receber influência direta da lógica da common law, positivada no diploma processual civil.

\section{RECURSOS QUe SERÃo ENCAMINHAdos PARA RETRATAÇÃo do ÓRGÃO NO QUAL FOI JULGADO O ACÓRDÃO RECORRIDO}

Como se vê do inciso II do art. 1030 do CPC $2015^{21}$, a segunda hipótese de deliberação, por parte da presidência ou vice-presidência do tribunal local ao realizar o juízo de admissibilidade do recurso especial e/ou extraordinário interposto, será a de encaminhar (ou devolver) o processo ao órgão que prolatou o acórdão recorrido para realização do juízo de retratação. Isso ocorrerá nas hipóteses em que o acórdão recorrido divergir de entendimentos proferidos em repercussão geral ou recurso repetitivo, proferidos pelo STF ou STJ, respectivamente ${ }^{22}$.

21 Art. 1.030. (...)II - encaminhar o processo ao órgão julgador para realização do juízo de retratação, se o acórdão recorrido divergir do entendimento do Supremo Tribunal Federal ou do Superior Tribunal de Justiça exarado, conforme o caso, nos regimes de repercussão geral ou de recursos repetitivos;

22 Abordando o tema, veja-se: CAMBI, Eduardo, DOTTI, Rogéria, PINHEIRO, Paulo Eduardo d'Arce, MARTINS, Sandro Gilberto; KOZIKOSKI, Sandro Marcelo. Curso de Processo Civil completo. São Paulo: RT, 2017, pg. 1612. 
Vê-se que, novamente, trata-se de desdobramento da nova sistemática atrelada aos precedentes, positivada pelo novo código de processo civil. Nesse caso, havendo deliberação por parte de Câmara ou Turma criminal local que destoe do(s) entendimento(s) de repercussão geral ou recursos repetitivos, determinará a presidência ou a vice-presidência do tribunal que seja realizada retratação pelo próprio órgão que realizou o julgamento combatido.

Exemplo poderia ser trazido à tona. Imagine acórdão de tribunal regional federal que declina a competência para a justiça estadual, de causa em que a primeira instância condenou o acusado pelo crime de disponibilizar vídeo pornográfico de adolescente pela internet ${ }^{23}$, em site acessível em qualquer parte do globo. O declínio da competência se fundou na circunstância de que não haveria ofensa a bens ou interesse da União. Em nosso exemplo, contra a referida decisão é interposto recurso extraordinário que sustenta que ao assim decidir, teria havido ataque ao art. 109, inciso V da Constituição Federal ${ }^{24}$. Como já fora o tema deliberado pelo Supremo Tribunal Federal em sede de repercussão geral, oportunidade em que se exarou o Tema 393, que consigna que "Compete à Justiça Federal processar e julgar os crimes consistentes em disponibilizar ou adquirir material pornográfico envolvendo criança ou adolescente (arts. 241, 241-A e 241-B da Lei 8.069/1990) quando praticados por meio da rede mundial de computadores", o recurso sequer seria apreciado, havendo a determinação, por parte da Presidência ou Vice-presidência da Corte respectiva de devolução dos autos para a Turma que proferiu o acórdão, de forma a que o julgamento fosse retomado para se afirmar a competência da justiça federal e subsequente deliberação do tema de fundo, qual seja, o mérito da acusação.

23 Art. 241-A da da Lei 8.069/1990: Oferecer, trocar, disponibilizar, transmitir, distribuir, publicar ou divulgar por qualquer meio, inclusive por meio de sistema de informática ou telemático, fotografia, vídeo ou outro registro que contenha cena de sexo explícito ou pornográfica envolvendo criança ou adolescente: Pena - reclusão, de 3 (três) a 6 (seis) anos, e multa.

Art. 109. Aos juízes federais compete processar e julgar: V - os crimes previstos em tratado ou convenção internacional, quando, iniciada a execução no País, o resultado tenha ou devesse ter ocorrido no estrangeiro, ou reciprocamente; 
Havendo a determinação da Presidência ou Vice-presidência para que haja o juízo de retratação, caberá à câmara ou turma, num primeiro momento, realizá-lo, reformando o acórdão anteriormente proferido. Com a respectiva publicação, é claro, poderá a parte que sucumbiu interpor os recursos apropriados. De outro lado, poderá também a turma ou a câmara refutar o juízo de retratação. Verticalizaremos essa hipótese, inclusive trazendo rápida explicação de como isso pode acontecer, em tópico abaixo.

\section{RECURSOS QUE SERÃO SOBRESTADOS - E AS QUESTÕES CORRELATAS DA MANUTENÇÃO DA PRISÃO CAUTELAR E DA PRESCRIÇÃO}

A terceira espécie de decisão que pode ser tomada pela presidência ou vice-presidência do tribunal local, ao realizar o juízo de admissibilidade do recurso especial e/ou extraordinário interposto, será a de sobrestar o recurso que tratar de temática com caráter repetitivo ainda não decidida pelo Supremo Tribunal Federal ou pelo Superior Tribunal de Justiça ${ }^{25}$, nos termos do inciso III do art. 1030 do CPC $/ 2015^{26}$.

O procedimento do julgamento dos recursos excepcionais repetitivos está previsto nos artigos 1.036 e seguintes do CPC/2015, bem como nos regimentos internos tanto do STJ quanto do STF. Indica-se ao leitor que se interessa no tema, a leitura dessas normativas que, em virtude dos limites do presente artigo, não serão aqui abordadas.

O que importa discutir agora é o fato de que é fundamental, para aqueles que se dedicam ao estudo e/ou ao trato prático dessas espécies recursais, o conhecimento dos temas em repercussão geral nos quais foi determinada a suspensão nacional dos processos em trâmite ${ }^{27}$,

25 Abordando o tema, veja-se: CAMBI, Eduardo, DOTTI, Rogéria, PINHEIRO, Paulo Eduardo d'Arce, MARTINS, Sandro Gilberto; KOZIKOSKI, Sandro Marcelo. Curso de Processo Civil completo. São Paulo: RT, 2017, pg. 1612.

26 Art. 1.030. (...) III - sobrestar o recurso que versar sobre controvérsia de caráter repetitivo ainda não decidida pelo Supremo Tribunal Federal ou pelo Superior Tribunal de Justiça, conforme se trate de matéria constitucional ou infraconstitucional;

27 Como se verifica no sítio eletrônico do Supremo Tribunal Federal: http:// www.stf.jus.br/portal/cms/verTexto.asp?servico=repercussaoTemas Suspensao\&pagina=principal. 
bem como as questões que foram submetidas a julgamento repetitivo ainda não encerrados ${ }^{28}$, para que as suspensões dos processos sejam devidamente realizadas, ou, caso contrário, sejam combatidas através dos recursos cabíveis.

Há dois pontos que merecem a nossa atenção nessa temática, e que serão pormenorizados nos subitens abaixo.

\section{1. É RAZOÁVEL A MANUTENÇão dA PRISÃo CAUTELAR EM PROCESSO SUSPENSO POR AGUARDAR DECISÃo FINAL DE REPERCUSSÃo GERAL OU RECURSO REPETITIVO?}

O primeiro dos desdobramentos que clamam nossa atenção diz respeito às consequências jurídicas do sobrestamento, após o juízo de admissibilidade de recurso especial ou extraordinário, de processo penal em que houve decretação de prisão preventiva nos termos do art. 312 do Código de Processo Penal ${ }^{29}$.

Não seria preciso dizer que tem sido bastante debatida a ilegalidade e a inconstitucionalidade da forma como tem sido decretada a prisão preventiva em nosso sistema jurídico, o que não será aprofundado na presente seara ${ }^{30}$. Mas, para além desse debate, que em virtude

28 Como se vê do sitio eletrônico do Superior Tribunal de Justiça: http://www. stj.jus.br/repetitivos/temas_repetitivos/pesquisa.jsp?\&l=10\&i=11

29 A Lei 13.964/2019 estabeleceu nova redação para o art. 312 do CPP: “Art. 312. A prisão preventiva poderá ser decretada como garantia da ordem pública, da ordem econômica, por conveniência da instrução criminal ou para assegurar a aplicação da lei penal, quando houver prova da existência do crime e indício suficiente de autoria e de perigo gerado pelo estado de liberdade do imputado".

30 Para uma análise crítica do fundamento da garantia da ordem pública, mesmo após o advento da Lei 12.403 de 2011, veja-se: SILVEIRA, Felipe Lazzari da. A banalização da prisão preventiva para a garantia da ordem pública. Revista da Faculdade de Direito da UFMG. Belo Horizonte, n. 67, p. 213-244, jul-dez 2015; MENDONÇA, Andrey Borges de. Análise crítica da prisão preventiva na Lei 12.403/2011: proposta à luz de modelos estrangeiros e da Convenção Americana de Direitos Humanos. Dissertação de Mestrado. Universidade de São Paulo. São Paulo, 2014. Também para uma análise crítica, com um enfoque mais amplo, confira-se o trabalho de WEDY, Miguel Tedesco. Teoria geral da prisão cautelar e estigmatização. Rio de Janeiro: Lumen Juris, 2006. O mesmo viés crítico, a partir de uma percepção sociológica, 
dos estreitos limites desse artigo, não será aqui retomado, mesmo que todas as prisões preventivas sempre fossem legais e constitucionais (enfatize-se o "mesmo que"), um outro nível de indagação ainda se impõe: seria razoável um recorrente aguardar preso o deslinde de um recurso judicial em processo de terceiro, em virtude do qual o seu próprio recurso está sobrestado? Não há como se responder afirmativamente à questão, levando-se em consideração os princípios constitucionais da celeridade processual ${ }^{31}$ e da presunção de inocência ${ }^{32}$, reitores da temática.

Para além dos princípios constitucionais referidos, tão combalidos nessa quadra, ainda há que se considerar os termos do $\S 4^{\circ}$ do art. 1.037 do CPC/2015 que impõe que sejam julgados em "até um ano" os recursos repetitivos e repercussões gerais. O fato é que o legislador já contava com a demora do Judiciário no momento de formulação da regra. Deve essa morosidade ser suportada pela parte, encarcerada, com recurso suspenso?

Diante de tais considerações, temos que não podem ser mantidas prisões preventivas decretadas em processos penais em que, no momento do juízo de admissibilidade do recurso especial ou extraordinário interpostos, viessem a ser suspensos em virtude de conexão com repetitivo ou repercussão geral. Manter a prisão de um acusado, em um processo que ficará suspenso por irrazoável tempo, no qual se debate tema que ainda não foi definitivamente deliberado pelo STF ou STJ, é algo que refoge aos limites estabelecidos pelos princípios constitucionais acima referidos.

é debatido em DUARTE, Samuel Correa. A prisão preventiva no sistema jurídico brasileiro: entre a proteção do acusado e a antecipação da pena presumida. RBSD - Revista brasileira de sociologia do direito, v. 6, n. 2, p. 40-62, maio/ago. 2019.

31 Art. 50, LXXVIII da CR: "a todos, no âmbito judicial e administrativo, são assegurados a razoável duração do processo e os meios que garantam a celeridade de sua tramitação".

32 Art. 50, LVII da CR: "ninguém será considerado culpado até o trânsito em julgado de sentença penal condenatória”; 


\subsection{COMO INCIDIRIA OS PRAZOS PRESCRICIONAIS EM PROCESSO SUSPENSO POR AGUARDAR DECISÃo final de REPERCUSSÃo GERAL OU RECURSO RePETITIVo?}

O segundo ponto que merece destaque no que se refere à sistemática dos sobrestamentos diz respeito à contagem do prazo prescricional. Parece não haver qualquer dúvida, considerando-se os marcos processuais que interrompem o prazo prescricional, delimitados nos termos do art. 117 do Código Penal ${ }^{33}$, que o sobrestamento do processo não trará repercussão à contagem do prazo prescricional. Principalmente se levarmos em conta que recentemente o instituto da prescrição foi reformado através da Lei 13.964/2019, e que tal aspecto não foi objeto de qualquer deliberação por parte do nosso Parlamento.

O destaque do ponto, contudo, não se trata de mero preciosismo. Em verdade, trata-se de debate a respeito do estabelecimento de balizas para discussão que porventura poderá advir no futuro, qual seja, a interpretação do inciso III do art. 116 do Código Penal, incluído pela lei acima referida, que assim dispõe: "Art. 116 - Antes de passar em julgado a sentença final, a prescrição não corre: (...) III - na pendência de embargos de declaração ou de recursos aos Tribunais Superiores, quando inadmissíveis;".

Como se vê da redação do inciso incluído, desde logo se verifica que no caso de decisão que inadmita recurso especial ou de recurso extraordinário interpostos contra acórdão condenatório de segundo grau, o prazo prescricional não correrá. Analisa-se no presente artigo que para além de um juízo que admite ou não admite o recurso dirigido ao tribunal superior, há em vigor em nosso sistema jurídico várias outras possibilidades de decisão após a interposição de recurso especial ou extraordinário. Dentre essas, como ora se analisa, a decisão que irá sobrestar o recurso, em virtude da vinculação da matéria nele veiculada a recurso, em tramite

33 Art. 117 - O curso da prescrição interrompe-se: I - pelo recebimento da denúncia ou da queixa; II - pela pronúncia; III - pela decisão confirmatória da pronúncia; IV - pela publicação da sentença ou acórdão condenatórios recorríveis; V - pelo início ou continuação do cumprimento da pena; VI pela reincidência. 
no STJ ou no STF, que esteja aguardando deliberação em caráter repetitivo ou nos termos de repercussão geral.

Temos que, nos contornos do inciso incluído, a única hipótese em que a prescrição deixará de correr será após decisão que inadmite o recurso especial ou extraordinário. Todas os outros tipos de decisão, dentre as quais, a decisão de sobrestamento de processos penais, em virtude de pendência de julgamento em sede de Repercussão Geral ou Recurso Repetitivo não é fundamento para a suspensão do prazo prescricional.

\section{RECURSOS CUJA ADMISSIBILIDAdE SERÁ ANALISADA E SELEÇÃo doS REPRESENTATIVOS DA CONTROVÉRSIA}

Retomando-se o tema central da presente investigação, e mirando-se o que já foi até aqui debatido, os recursos excepcionais podem ser desde logo negados, sobrestados, ou retratados, em função do entendimento dos tribunais superiores acerca do tema discutido. Nada obstante, para além destas hipóteses, a presidência ou vice-presidência da Corte de origem, terá uma quarta alternativa: realização do juízo de admissibilidade, que poderá ser positivo ou negativo. É o que se debate nos subitens abaixo.

\subsection{Juízo DE ADMISSIBILIDADE DOS RECURSOS}

Nos termos do inciso V do art. 1030 do CPC/2015, o órgão responsável poderá "realizar juízo de admissibilidade e, se positivo, remeter o feito ao Supremo Tribunal Federal ou ao Superior Tribunal de Justiça (...)"34. Será positivo se estiverem satisfeitos todos os requisitos ordinários, constitucionais e específicos como por exemplo matéria prequestionada, não se tratar de questão de fato ou de prova, e haver decisão de outro Tribunal local, ou do próprio Tribunal Superior que

34 Abordando o tema, veja-se: CAMBI, Eduardo, DOTTI, Rogéria, PINHEIRO, Paulo Eduardo d'Arce, MARTINS, Sandro Gilberto, e KOZIKOSKI, Sandro Marcelo. Curso de Processo Civil completo. São Paulo: RT, 2017, pg. 1612. 
destoe da decisão recorrida. O juízo será negativo, em contrapartida, se algum, ou alguns, desses requisitos não tiver sido atendido: se o tema não foi prequestionado, se a discussão objeto do recurso for de questão fático-probatória, ou ainda, se o entendimento esposado pela decisão recorrida confirma aquilo que tem decidido os tribunais superiores sobre o tema.

Inexistindo quaisquer óbices, o recurso poderá ser admitido, desde que, nos termos das alíneas do inciso V que ora se comenta, a) o recurso ainda não tenha sido submetido ao regime de repercussão geral ou de julgamento de recursos repetitivos; b) o recurso tenha sido selecionado como representativo da controvérsia; ou c) o tribunal recorrido tenha refutado o juízo de retratação.

Se o tema do recurso, nos termos da alínea "a", foi submetido ao regime de repercussão geral ou de recursos repetitivos através de recurso anterior, ele não será admitido, será sobrestado. Como acima visto, não há razão para discussões paralelas no âmbito do STF e do STJ, se o objetivo é dotar a interpretação de caráter vinculante. Assim, se já há um recurso que debata o tema, novas discussões sobre a mesma temática serão sobrestadas.

A situação descrita na alínea "c" diz respeito à refutação do juízo de retratação pela câmara ou turma que proferiu o julgamento recorrido. Como visto, pode entender o órgão que realiza o juízo de admissibilidade que o acórdão recorrido desatende os preceitos de uma determinada orientação em sede de repercussão geral ou recurso repetitivo. E após enviar o feito para que o órgão refaça o julgamento, este entende que o precedente não se aplica à hipótese. Nesse caso, o recurso deverá ser conhecido, para que o desacordo entre Presidência ou Vice-Presidência do órgão e a câmara ou turma da qual emanou o acórdão, seja sanado no bojo do recurso especial ou extraordinário interposto.

Tome-se um exemplo de como isso tem ocorrido na prática, conforme se recolhe da jurisprudência sobre o tema, mais especificamente na Reclamação 37.584/RS, Relatada pelo Ministro Ribeiro Dantas, em julgamento realizado pela Terceira Seção do Superior Tribunal de Justiça em 12/06/2019 ${ }^{35}$. No caso, o Tribunal de Justiça do Rio Grande

35 DJe 18/06/2019. 
do Sul, ao dar provimento a recurso defensivo, declarou a extinção da punibilidade do acusado, em virtude de já haver expirado o período de prova do benefício da suspensão condicional do processo. O Ministério Público local interpôs Recurso Especial, esgrimindo o argumento de que descumpridas as condições impostas durante o período de prova da suspensão condicional do processo, o benefício poderá ser revogado, mesmo se já ultrapassado o prazo legal, desde que referente a fato ocorrido durante sua vigência, como dispôs a decisão do Superior Tribunal de Justiça no REsp 1.498.034/RS. Processado o recurso especial, a Vice-Presidência daquele Corte determinou a remessa dos autos à $7^{\text {a }}$ Câmara Criminal do TJRS - de onde se originou a decisão combatida no recurso - e em juízo de retratação, o referido órgão julgador manteve o seu entendimento. Após, foi admitido o recurso especial. Antes do apelo raro ser julgado, ingressou o Ministério Público com a Reclamação em referência, a qual foi julgada procedente, tendo-se em conta justamente o entendimento firmado pelo STJ no acima citado REsp 1.498.034/RS.

A discussão realizada no segundo requisito para a realização de juízo admissibilidade, qual seja a de que o recurso tenha sido selecionado como representativo da controvérsia merece ser verticalizada em item próprio, como se faz abaixo.

\subsection{Seleção de ReCURSo Representativo de CONTROVÉrsia}

Tratam os art. 1036 e seguintes do CPC 2015 do procedimento de julgamento dos recursos repetitivos. Trata-se de mecanismo de deliberação de questões de direito que se apresentam em múltiplos recursos manejados por inúmeras partes de processos judiciais, realizado no STF ou STJ, conforme respectivas competências. Basicamente, selecionam os tribunais locais recursos denominados de "representativos da controvérsia”, ou seja, recursos que tragam questões que insistentemente tem sido aventadas pelas partes, remetendo-as à Corte competente para o respectivo julgamento e pacificação do tema.

Levando tal sistemática em consideração, optou o legislador por regular essa hipótese no âmbito do juízo de admissibilidade dos recursos 
excepcionais. De tal forma, sendo admitido o recurso excepcional, nos termos do inciso IV do art. 1030 ora em comento, a presidência ou vice -presidência do Tribunal de origem poderá "selecionar o recurso como representativo de controvérsia constitucional ou infraconstitucional, nos termos do $\$ 6^{\circ}$ do art. 1.036".

O $\S 6^{\circ}$ do art. 1.036 do CPC 2015 trata da necessidade de que os recursos escolhidos contenham abrangente argumentação e discussão a respeito da questão a ser decidida. Nos termos do $§ 1^{\circ}$ do mesmo artigo, "O presidente ou o vice-presidente de tribunal de justiça ou de tribunal regional federal selecionará 2 (dois) ou mais recursos representativos da controvérsia, que serão encaminhados ao Supremo Tribunal Federal ou ao Superior Tribunal de Justiça para fins de afetação, determinando a suspensão do trâmite de todos os processos pendentes, individuais ou coletivos, que tramitem no Estado ou na região, conforme o caso".

Procedimento ligado a tal sistemática, e que se dá ainda no bojo do juízo de admissibilidade diz respeito ao §2o desse artigo, que assim consigna: "O interessado pode requerer, ao presidente ou ao vice-presidente, que exclua da decisão de sobrestamento e inadmita o recurso especial ou o recurso extraordinário que tenha sido interposto intempestivamente, tendo o recorrente o prazo de 5 (cinco) dias para manifestar-se sobre esse requerimento".

\section{Conclusões}

Como se vê, o debate que gira em torno do juízo de admissibilidade dos recursos raros, nos termos do inciso I do art. 1030 do CPC 2015, demanda um conhecimento dos temas cuja repercussão geral foi reconhecida, bem como dos temas cuja repercussão não foi reconhecida, o que pode ser pesquisado no sítio eletrônico do próprio Supremo Tribunal Federal. Da mesma forma, torna-se imprescindível estar a par dos temas que foram objeto de deliberação, por parte do Superior Tribunal de Justiça, no regime dos recursos repetitivos. Como aduz Côrtes, "a ordem ora imposta é, ao contrário do histórico evolutivo anterior da nossa legislação, a de haver uma preocupação maior em assegurar a observância a teses firmadas em leading cases, e menos a de criar e estimular 
o desenvolvimento de mecanismos recursais casuais e individuais para corrigirem erros de julgamento" ${ }^{36}$.

De tal forma, e retomando-se as indagações que foram propostas no início desse artigo, podemos responder da seguinte forma: sim, foi modificado o regime jurídico do juízo de admissibilidade dos recursos especiais e extraordinários criminais com as alterações ocorridas no Novo Código de Processo Civil (CPC 2015), como inclusive o demonstram as decisões que têm sido proferidas pelos Tribunais Superiores citadas ao longo desse trabalho. Tendo havido uma modificação na sistemática do juízo prefacial dos recursos raros criminais, é de se ressaltar que, coerentes à sistemática dos precedentes que vai ocupando seu espaço em nosso sistema jurídico, nos termos do CPC 2015, poderão as Cortes locais, desde logo, negar seguimento, indeferir, e sobrestar recursos, cujos temas já tenham sido apreciados ou estejam sendo analisados pelo STF e STJ.

Por fim, e diante desse novo quadro, o cotidiano forense das partes que manejam os recursos especial e extraordinários será profundamente impactado, visto que, para além do conhecimento da Constituição da República, da legislação infraconstitucional, e da jurisprudência aplicável ao caso concreto, deverá ainda a parte, também nos processos penais, conhecer os temas que foram pacificados pelas Cortes Superiores, e aos quais foram dados efeitos erga omnes, como ocorre na sistemática aqui analisada.

\section{REFERÊNCIAS}

ARENHART, MITIDIERO, e outro. Novo Curso de Processo Civil: tutela dos direitos mediante procedimento comum, volume II. São Paulo: Thomson Reuters/Revista dos Tribunais, 2015.

BADARÓ, Gustavo. Manual dos recursos penais. São Paulo: Thomson Reuters, 2018.

36 CÔRTES, Osmar Mendes Paixão. Recursos para os tribunais superiores: recurso extraordinário, recurso especial, embargos de divergência e agravos. $4^{\mathrm{a}}$ ed. Brasília: Gazeta Jurídica, 2017. 
CAMBI, Eduardo, DOTTI, Rogéria, PINHEIRO, Paulo Eduardo d'Arce, MARTINS, Sandro Gilberto, e KOZIKOSKI, Sandro Marcelo. Curso de Processo Civil completo. São Paulo: Editora Revista dos Tribunais, 2017.

CÔRTES, Osmar Mendes Paixão. Recursos para os tribunais superiores: recurso extraordinário, recurso especial, embargos de divergência e agravos. $4^{\mathrm{a}}$ ed. Brasília: Gazeta Jurídica, 2017.

DUARTE, Samuel Correa. A prisão preventiva no sistema jurídico brasileiro: entre a proteção do acusado e a antecipação da pena presumida. RBSD - Revista brasileira de sociologia do direito, v. 6, n. 2, p. 40-62, maio/ago. 2019.

HORTA, André Frederico e NUNES, Dierle. Aplicação de precedentes e distinguishing no CPC/2015: uma breve introdução. In: Precedentes (Coleção Grandes Temas do Novo CPC, v. 3). DIDIER JR., Fredie... et al. Salvador: Juspodium, 2016.

KIRCHER, Luis Felipe. Uma Teoria dos Precedentes Vinculantes no Processo Penal. Salvador: JusPodivm, 2018.

LOPES FILHO, Juraci Mourão. Os precedentes judiciais no constitucionalismo contemporâneo. 2 ed. rev. e atual. Salvador: Juspodium, 2016; TARUFFO, Michele. Precedente e jurisprudência. In: Revista de Processo: RePro, v. 36, n. 199, set. 2011.

LOPES JR., Aury. Direito processual penal. 9. ed. rev. E atual. São Paulo: Saraiva, 2012.

MANGONE, Katia Aparecida. Prequestionamento e questões de ordem pública no recurso extraordinário. São Paulo: Editora Saraiva, 2013.

MEDINA, José Miguel Garcia. Prequestionamento e repercussão geral e outras questões relativas aos recursos especial e extraordinário. $5^{\mathrm{a}}$ ed. rev. e amp. São Paulo: Editora Revista dos Tribunais, 2009.

MELLO, Patrícia Perrone Campos. Precedentes: o desenvolvimento judicial do direito no constitucionalismo contemporâneo. São Paulo: Renovar, 2008.

MENDONÇA, Andrey Borges de. Análise crítica da prisão preventiva na Lei 12.403/2011: proposta à luz de modelos estrangeiros e da Convenção Americana de Direitos Humanos. Dissertação de Mestrado. Universidade de São Paulo. São Paulo, 2014.

OLIVEIRA, Ana Carolina. Diferenças e semelhanças entre os sistemas da civil law e da common law. In: Direito Público (Porto Alegre), vol. 12, n. 64, 2015, p. 109-126. PORTELLA, Glória Maria Guimarães de Pádua Ribeiro. Teoria crítica do recurso especial (jurisprudência e doutrina) Rio de Janeiro: Editora Lumen Juris, 2004. 
RANGEL, Paulo. Direito processual penal. 22. ed. São Paulo: Atlas, 2014.

ROCHA JÚNIOR, Francisco de Assis do Rego Monteiro. Recurso Especial e Extraordinário Criminais. São Paulo: Saraiva, 2013.

SILVEIRA, Felipe Lazzari da. A banalização da prisão preventiva para a garantia da ordem pública. Revista da Faculdade de Direito da UFMG. Belo Horizonte, n. 67, p. 213-244, jul-dez 2015.

STRECK, Lênio Luiz e ABBOUD, Georges. O que é isto - o precedente judicial e as súmulas vinculantes? Porto Alegre: Livraria do Advogado, 2014

STRECK, Lenio Luiz. Precedentes Judiciais e Hermeneutica: o sentido da vinculação no CPC/2015. Salvador: Juspodium, $2^{\text {a }}$ edição, 2019.

VASCONCELLOS, Vinicius G. Direito ao recurso no processo penal. São Paulo: RT, 2019.

WEDY, Miguel Tedesco. Teoria geral da prisão cautelar e estigmatização. Rio de Janeiro: Lumen Juris, 2006.

ZANETI JR., Hermes. Precedentes normativos formalmente vinculantes. In: Precedentes (Coleção Grandes Temas do Novo CPC, v. 3). DIDIER JR., Fredie... et al. Salvador: Juspodium, 2016. 


\section{Informações adicionais e declarações dos autores (integridade científica)}

Declaração de conflito de interesses (conflict of interest declaration): o autor confirma que não há conflitos de interesse na realização das pesquisas expostas e na redação deste artigo.

Declaração de autoria e especificação das contribuições (declaration of authorship): todas e somente as pessoas que atendem os requisitos de autoria deste artigo estão listadas como autores; todos os coautores se responsabilizam integralmente por este trabalho em sua totalidade.

Declaração de ineditismo e originalidade (declaration of originality): o autor assegura que o texto aqui publicado não foi divulgado anteriormente em outro meio e que futura republicação somente se realizará com a indicação expressa da referência desta publicação original; também atesta que não há plágio de terceiros ou autoplágio. 
Dados do processo editorial

(http://www.ibraspp.com.br/revista/index.php/RBDPP/about/editorialPolicies)

- Recebido em: 28/08/2019

Equipe editorial envolvida

- Controle preliminar e verificação de plágio:

- Editor-chefe: 1 (VGV) 28/11/2019

- Avaliação 1: 13/12/2019

- Revisores: 3

- Avaliação 2: 14/12/2019

- Avaliação 3: 23/12/2019

- Decisão editorial preliminar: 26/12/2019

- Retorno rodada de correções: 22/01/2020

- Decisão editorial final: 16/02/2020

\section{COMO CITAR ESTE ARTIGO:}

ROCHA JR., Francisco Monteiro. O regime jurídico do juízo de admissibilidade dos recursos criminais dirigidos aos Tribunais Superiores conforme o CPC/2015. Revista Brasileira de Direito Processual Penal, Porto Alegre, vol. 6, n. 1, p. 423-450, jan./abr. 2020. https://doi.org/10.22197/rbdpp.v6i1.274

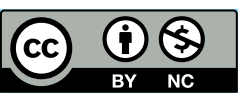

Esta obra está licenciada com uma Licença Creative Commons Atribuição-NãoComercial 4.0 Internacional. 